\title{
PENILAIAN RISIKO SANITASI LINGKUNGAN DI PULAU BALANG LOMPO KELURAHAN MATTIRO KABUPATEN PANGKAJENE DAN KEPULAUAN
}

\author{
Andi Susilawaty ${ }^{1}$, Abdul Majid HR. Lagu ${ }^{2}$, Syahrul Basri ${ }^{3}$, \\ Ultry Maisari ${ }^{4}$, Munawir Amansyah ${ }^{5}$

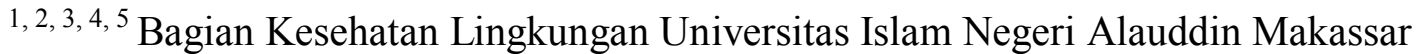

\begin{abstract}
ABSTRAK
Penilaian risiko sanitasi lingkungan atau yang juga dikenal dengan Environmental Health Risk Assessment (EHRA) adalah studi untuk memahami kondisi fasilitas sanitasi dan perilaku-perilaku yang berisiko pada kesehatan masyarakat. Penelitian ini bertujuan untuk mendapatkan gambaran analisis risiko sanitasi lingkungan di Pulau Balang Lompo Kelurahan Mattiro Sompe Kecamatan Liukang Tupabbiring Kabupaten Pangkajene dan Kepulauan. Jenis penelitian yang digunakan adalah kuantitatif dengan pendekatan analitik. Responden dalam penelitian ini sebanyak 65 ruman yang diambil dengan simple random sampling. Data diolah dengan menggunakan SPSS 17.0 dan disajikan dalam bentuk tabel sederhana atau tabel frekuensi untuk analisis univariat. Hasil penelitian diperoleh bahwa bahaya-bahaya sanitasi lingkungan di Pulau Balang Lompo meliputi bahaya terkait kepemilikan tempat sampah $(58,5 \%)$ dan air limbah domestik (37,4\%). Adapun beberapa perilaku tidak sehat yang memberikan peluang keterpaparan bahaya, yaitu perilaku tidak Cuci Tangan Pakai Sabun (47,7\%), Buang Air Besar Sembarangan (29,2\%), tidak memilah sampah $(83,1 \%)$, serta perilaku tidak melakukan penanganan sampah $(84,6 \%)$. Sehingga dapat disimpulkan bahwa tingkat risiko sanitasi lingkungan di Pulau Balang Lompo menunjukkan bahwa RW 1 berada pada kategori Risiko sangat tinggi dengan nilai indeks risiko 191, RW 2 dengan kategori Risiko rendah dengan nilai indeks risiko 124, RW 3 dengan kategori Risiko rendah dengan nilai indeks risiko125 dan untuk RW 4 dengan kategori Risiko rendah dengan nilai indeks risiko 135. Beberapa faktor yang menjadi penyebab risiko sangat tinggi di RW 1 adalah penduduk yang menyimpang dari perilaku hidup sehat, tingkat pendidikan, kurangnya kepemilikan tempat sampah, kepemilikan SPAL dan kepemilikan jamban, serta tingginya tingkat kebiasaan Buang Air Besar Sembarangan. Dalam hal ini, diperlukan risk communication agar masyarakat mengetahui dan memahami besaran risiko sanitasi lingkungan tempat tinggalnya, sehingga ada upaya pencegahan dalam bentuk peningkatan cakupan rumah tangga dan individu berperilaku bersih dan sehat.
\end{abstract}

Kata Kunci : Risiko, Sanitasi Lingkungan

\section{PENDAHULUAN}

Penilaian risiko kesehatan lingkungan atau yang juga dikenal dengan Environmental Health Risk Assessment (EHRA) adalah studi untuk memahami kondisi fasilitas sanitasi dan perilaku-perilaku yang berisiko pada kesehatan masyarakat. Fasilitas sanitasi yang diteliti mencakup sumber air bersih (SAB), fasilitas jamban yang sehat, tempat sampah rumah tangga, dan saluran pembuangan air limbah (SPAL) rumah tangga. Untuk perilaku, yang dipela- 
jari adalah perilaku cuci tangan pakai sabun (CTPS), perilaku pemilahan sampah dan buang air besar sembarangan, (ISSDP, 2007). yang tinggi pada anak dengan proporsi 31.4\%. Di Indonesia diare masih merupakan penyebab utama kematian anak berusia di bawah lima tahun. Sedangkan persentase

Tabel 1. Karakteristik Responden dan Sampel Penelitian

\begin{tabular}{|c|c|c|c|c|c|c|c|c|c|c|}
\hline \multirow{3}{*}{ VARIABEL } & \multicolumn{8}{|c|}{ RW } & \multirow{2}{*}{\multicolumn{2}{|c|}{ Total }} \\
\hline & \multicolumn{2}{|c|}{1} & \multicolumn{2}{|c|}{2} & \multicolumn{2}{|c|}{3} & \multicolumn{2}{|c|}{4} & & \\
\hline & $\mathrm{n}$ & $\%$ & $\mathrm{n}$ & $\%$ & $\mathrm{n}$ & $\%$ & $\mathrm{n}$ & $\%$ & $\mathrm{~N}$ & $\%$ \\
\hline \multicolumn{11}{|l|}{ Kepemilikan Tempat Sampah } \\
\hline Tidak Memiliki Tempat Sampah & 14 & 21,5 & 9 & 13,9 & 9 & 13,9 & 6 & 9,2 & 38 & 58,5 \\
\hline Buang Sampah Ke Laut & 13 & 20 & 10 & 15,3 & 10 & 15,3 & 11 & 16,9 & 44 & 67,5 \\
\hline Penanganan di buang ke laut & 15 & 23,1 & 13 & 20 & 13 & 20 & 14 & 21,5 & 55 & 84,6 \\
\hline Dibakar & 2 & 3,1 & 3 & 4,6 & 3 & 4,6 & 2 & 3,1 & 10 & 15,4 \\
\hline Setiap Hari Buang Sampah & 15 & 23,1 & 12 & 18,4 & 13 & 20 & 9 & 13,8 & 49 & 75,3 \\
\hline Lalat berkembang biak di Sampah & 14 & 21,5 & 14 & 21,5 & 9 & 13,9 & 8 & 12,3 & 45 & 69,2 \\
\hline \multicolumn{11}{|l|}{ Air Limbah Domestik } \\
\hline Tidak Memiliki Jamban & 7 & 10,8 & 3 & 4,6 & 2 & 3,1 & 7 & 10,7 & 19 & 29,2 \\
\hline BAB Ke Laut & 6 & 9,3 & 3 & 4,6 & 1 & 1,5 & 7 & 10,8 & 17 & 26,2 \\
\hline Tidak Punya Kloset & 7 & 10,8 & 3 & 4,6 & 2 & 3,0 & 7 & 10,8 & 19 & 29,2 \\
\hline BALIT BAB di Lantai & 6 & 9,2 & 6 & 9,2 & 6 & 9,2 & 6 & 9,2 & 24 & 36,8 \\
\hline Tidak memiliki SPAL & 11 & 16,9 & 3 & 4,6 & 7 & 10,8 & 8 & 12,3 & 29 & 44,6 \\
\hline Alirkan Limbah Ke halaman & 10 & 15,4 & 3 & 4,6 & 6 & 9,2 & 6 & 9,2 & 25 & 38,4 \\
\hline \multicolumn{11}{|l|}{ Perilaku Higiene dan Sanitasi } \\
\hline Cuci Tangan Setelah Makan & 13 & 20,0 & 7 & 10,7 & 4 & 6,2 & 6 & 9,2 & 30 & 46,1 \\
\hline Setelah Buang Air Besar & 3 & 4,7 & 6 & 9,2 & 6 & 9,2 & 5 & 7,7 & 20 & 30,8 \\
\hline Tidak Melakukan & 1 & 1,5 & 3 & 4,7 & 6 & 9,2 & 5 & 7,7 & 15 & 23,1 \\
\hline
\end{tabular}

Sumber :Data Primer, 2017

Sebanyak 40,2\% penduduk Indonesia belum mendapatkan akses sanitasi yang layak. Indonesia mengalami kerugian ekonomi sebesar Rp56,7 triliun per tahun akibat kondisi sanitasi buruk. Prevalensi Nasional Diare menunjukkan sebesar 7\% dan merupakan penyebab kematian paska kelahiran penduduk berakses sanitasi layak per Kabupaten/ Kota di Sulawesi Selatan tahun 2014 bahwa pembuangan akhir tinja rumah tangga di Sulawesi Selatan sebagian besar menggunakan tangki septik atau masih ada rumah tangga dengan pembuangan akhir tinja tidak ke tangki septic (SPAL, kolam/ 
sawah, langsung ke sungai/ danau/ laut, lubang tanah, atau pantai/ kebun) dengan capaian tertinggi yaitu Kabupaten Selayar $(99,52 \%)$ dan terendah di Kabupaten Takalar (5,07\%), sementara di kabupaten Pangkep sebanyak 38,2\%. (Riskesdas, 2013).

Menurut Kecamatan dan Puskesmas di Kecamatan Liukang Tupabbiring terdapat 3 desa. Dimana ada 1 desa yang melaksanakan STBM, 1 desa stop BABS, dan 1 desa STBM masing-masing dengan presentase 33,33\%. Dan presentase sepuluh penyakit tertinggi di puskesmas Liukang Tupabbiring yaitu hipertensi sedangkan penyakit diare berada pada urutan kedelapan. Kelurahan Mattiro Sompe merupakan salah satu Kelurahan yang berada di wilayah Koordinasi Kecamatan Liukang Tupabbiring. Kelurahan Mattiro Sompe sampai dengan tahun 2016 berjumlah 3328 jiwa terdiri dari laki - laki 1653 jiwa , perempuan 1675 jiwa dan 795 Kepala Keluarga dengan mata pencaharian sebagian besar masyarakatnya adalah nelayan. Untuk data jamban keluarga sebanyak 230, tempat sampah sebanyak 412, dan SPAL 412 dari Puskesmas Liukang Tupabbiring tahun 2016. Letaknya yang dekat dengan daratan utama Pulau Sulawesi menjadikan warga yang berdiam di pulau lebih banyak berinteraksi dengan Kabupaten Pangkep dan Kota Makassar. Kondisi ini yang men- yebabkan arus barang dan jasa di wilayah tersebut lebih banyak tercurah pada wilayah Kabupaten Pangkep dan Kota Makassar dibandingkan di pulau-pulau itu sendiri. Kelurahan Mattiro Sompe banyak yang tidak berdasarkan kebutuhan penduduk yang terdapat di pulau-pulau kecil tersebut, yang menyebabkan semakin besarnya tingkat kerentanan pulau-pulau kecil. Jika ada pembangunan yang berdasarkan kebutuhan penduduk, jumlahnya sangat sedikit, dan pembangunan itu sendiri tidak berdasarkan kesesuaian lahan dan daya dukung pulau kecil, ditambah lagi dengan prilaku masyarakat pulau yang menggunakan sumberdaya yang ada secara destruktif dan kondisi alam yang secara gradual akan mengalami perubahan akibat terjadinya perubahan iklim seperti halnya kenaikan muka laut (sea level rise). (Data Profil Kesehatan Kabupaten Pangkep, 2016)

Penelitian mengenai penilaian risiko kesehatan lingkungan yang dilakukan dibeberapa pulau-pulau di Sulawesi Selatan yaitu penelitian di Dusun Kokoa diperoleh bahwa bahaya-bahaya kesehatan lingkungan di Dusun Kokoa meliputi bahaya terkait sumber air bersih $(71,1 \%)$, air limbah domestik $(71,2 \%)$ dan kepemilikan tempat sampah $(72,5 \%)$. Adapun beberapa perilaku tidak sehat yang memberikan peluang keterpaparan bahaya, yaitu perilaku 
tidak Cuci Tangan Pakai Sabun (CTPS) (54,2\%), Buang Air Besar Sembarangan (BABS) (62,7\%), tidak mengolah dan mengelolah sampah rumah tangga $(96,1 \%)$ serta perilaku tidak mengolah air minum $(25,5 \%)$. Sehingga dapat disimpulkan bahwa tingkat risiko kesehatan ling-kungan di Dusun Kokoamenunjukkan bahwa risiko gan di Pulau Balang Lompo Kelurahan Mattiro Sompe', Kecamatan Liukang Tupabbiring Kabupaten Pangkajene dan Kepulauan Tahun 2017”.

\section{BAHAN DAN METODE}

Jenis penelitian yang digunakan adalah penelitian kuantitatif dengan pendekatan

Tabel 2. Indeks Risiko Sanitasi Lingkungan

\begin{tabular}{|c|c|c|c|c|c|c|c|c|c|}
\hline \multirow{3}{*}{ Variabel } & \multirow{3}{*}{$\begin{array}{l}\text { Jawa- } \\
\text { ban }\end{array}$} & \multicolumn{8}{|c|}{ RW } \\
\hline & & \multicolumn{2}{|r|}{1} & \multicolumn{2}{|c|}{2} & \multicolumn{2}{|r|}{3} & \multicolumn{2}{|c|}{4} \\
\hline & & $\mathrm{n}$ & $\%$ & $\mathrm{n}$ & $\%$ & $\mathrm{n}$ & $\%$ & $\mathrm{n}$ & $\%$ \\
\hline \multicolumn{10}{|l|}{ Tempat Sampah Respomden } \\
\hline Tidak Memiliki Tempat Sampah & Ya & 14 & 82,3 & 9 & 56,2 & 9 & 56,2 & 6 & 37,5 \\
\hline \multicolumn{10}{|l|}{ Air Limbah Domestik } \\
\hline Tidak Memiliki Jamban & $\mathrm{Ya}$ & 7 & 41,1 & 3 & 18,7 & 2 & 12,5 & 7 & 43,7 \\
\hline Tidak Memiliki SPAL & $\mathrm{Ya}$ & 11 & 64,7 & 3 & 18,7 & 7 & 43,7 & 8 & 50,0 \\
\hline $\begin{array}{l}\text { Limbah Rumah Tangga di } \\
\text { alirkan Ke halaman }\end{array}$ & $\mathrm{Ya}$ & 10 & 58,8 & 3 & 18,7 & 6 & 37,5 & 6 & 37,5 \\
\hline \multicolumn{10}{|l|}{ Perilaku Tidak Sehat } \\
\hline Perilaku BABS & $\mathrm{Ya}$ & 7 & 41,1 & 3 & 18,7 & 2 & 12,5 & 7 & 41,1 \\
\hline Pemilahan Sampah & Tidak & 17 & $\begin{array}{l}100 \\
0\end{array}$ & 13 & 81,2 & 10 & 62,5 & 14 & 87,6 \\
\hline Penanganan Pemilahan Sampah & Tidak & 15 & 88,2 & 13 & 81,2 & 13 & 81,2 & 14 & 87,6 \\
\hline $\begin{array}{c}\text { Kebiasaan Cuci Tangan Pakai } \\
\text { Sabun }\end{array}$ & Tidak & 7 & 41,1 & 10 & 62,5 & 7 & 43,7 & 7 & 43,7 \\
\hline
\end{tabular}

Sumber :Data Primer, 2017

dengan kategori sangat tinggi terdapat di RT 03, risiko dengan katori tinggi ada di RT 02, dan risiko rendah ada di RT 01 (Marwah, 2014).

Berdasarkan uraian diatas, peneliti tertarik untuk melakukan penelitian, dengan judul "Penilaian Risiko Sanitasi Lingkun- analitik menggunakan metode EHRA (Evinronmental Health Risk Assessment), yang bertujuan untuk mendapatkan gambaran bahaya kesehatan sanitasi lingkungan dan kondisi fasilitas sanitasi yang berisiko pada masyarakat di Pulau Balang Lompo Kelurahan Mattiro Sompe Kecamatan Liu- 
kang Tupabbiring Kabupaten Pangkajene dan Kepulauan (Pangkep) Tahun 2017.

Teknik sampling yang digunakan dalam penelitian ini adalah propotional sampling sehingga sampel dalam penelitian ini adalah sebanyak 65 rumah yang ada di Pulau Balang Lompo Kelurahan Mattiro Sompe Kecamatan Liukang Tupabbiring penelitian dan lembar observasi. Data yang telah dikumpulkan kemudian diinput menggunakan program epidata versi 31 dan dianalisis dengan menggunakan program Software Statistical Package for Social Science (SPSS) versi 17.0. Analisis data yang digunakan adalah deskriptif, yaitu membuat interpretasi dan narasi dari tiap-tiap

Tabel 3. Kalkulasi Indeks Risiko Sanitasi Lingkungan

\begin{tabular}{|c|c|c|c|c|c|}
\hline \multirow{3}{*}{ Variabel } & \multirow{3}{*}{$\begin{array}{c}\text { Bobot } \\
(\%)\end{array}$} & \multicolumn{4}{|c|}{ RW } \\
\hline & & 1 & 2 & 3 & 4 \\
\hline & & $\mathrm{n}$ & $\mathrm{n}$ & $\mathrm{n}$ & $\mathrm{n}$ \\
\hline Tempat Sampah Responden & & 82 & 56 & 56 & 38 \\
\hline Tidak Memiliki Tempat Sampah & 100 & 82 & 56 & 56 & 38 \\
\hline Air Limbah Domestik & & 53 & 18 & 30 & 42 \\
\hline Tidak Memiliki Jamban & 33 & 13 & 6 & 4 & 14 \\
\hline Tidak Memiliki SPAL & 33 & 21 & 6 & 14 & 16 \\
\hline $\begin{array}{c}\text { Limbah Rumah Tangga di Alirkan Ke ha- } \\
\text { laman }\end{array}$ & 33 & 19 & 6 & 12 & 12 \\
\hline Perilaku Tidak Sehat & & 56 & 50 & 39 & 55 \\
\hline Perilaku BABS & 40 & 16 & 7 & 5 & 16 \\
\hline Pemilahan Sampah & 15 & 15 & 12 & 9 & 13 \\
\hline Penanganan Sampah yang dipilah & 15 & 13 & 12 & 12 & 13 \\
\hline Kebiasaan Cuci Tangan Pakai Sabun & 30 & 12 & 19 & 13 & 13 \\
\hline
\end{tabular}

Sumber :Data Primer, 2017

Kabupaten Pangkajene dan Kepulauan Tahun 2017. Sedangkan responden pada penelitian ini yaitu wanita yang ditemukan saat melakukan penelitian yang bersedia untuk diwawancarai dengan umur $18-60$ tahun. Istrumen yang digunakan dalam penelitian ini adalah berupa kuisioner data variabel yang diperoleh serta presentasi yang berkaitan dengan tujuan penelitian dalam bentuk tabel sederhana atau tabel frekuensi untuk analisis univariat .

\section{HASIL PENELITIAN}

Hasil Analisis Kepemilikan Tempat Sam- 
pah.

Terkait dengan kepemilikan tempat sampah, sekitar 58,5\% rumah responden tidak memiliki tempat sampah. Dan untuk tempat pembuangan sampah sekitar $67,5 \%$ yang membuang kelaut. Dimana presentasi tertinggi adalah RW 1 yang paling banyak tidak memiliki tempat sampah dan menjadikan laut sebagai tempat pembuangan sam- gan catatan bahwa mereka setia hari membuang sampahnya ke laut sehingga kondisi sampah di lingkungan rumah dengan lalat berkembang biak di sampah berdasarkan observasi sebesar 69,2\%. Dimana presentase tertinggi di RW 1. Sebanyak 83,1\% rumah tangga tidak melakukan pemilahan sampah dari 65 rumah responden. Dimana presentase tertinggi yang paling banyak ti-

Tabel 4. Kumulatif Indeks Risiko Sanitasi Lingkungan

\begin{tabular}{lcccc}
\hline \multirow{2}{*}{ Variabel } & \multicolumn{4}{c}{ RW } \\
\cline { 2 - 5 } & 1 & 2 & 3 & 4 \\
\hline Tempat Sampah Responden & 82 & 56 & 56 & 38 \\
Air Limbah Domestik & 53 & 18 & 30 & 42 \\
Perilaku Tidak Sehat & 56 & 50 & 39 & 55 \\
\hline Total & 191 & 124 & 125 & 135 \\
\hline
\end{tabular}

Sumber :Data Primer, 2017

pah. Penanganan sampah di Pulau Balang Lompo itu sendiri, sekitar $84,6 \%$ di buang ke laut, sisanya 15,4\% warga melakukan penanganan sampah tanpa pemilahan dengan cara dibakar. Dimana presentase tertinggi yang paling banyak tidak melakukan penanganan sampah adalah di RW 1 mereka langsung membuang sampahnya ke laut sedangkan untuk presentase tertinggi yang melakukan penanganan sampah dengan cara di bakar adalah RW 2 dan RW 3. Untuk intensitas pembuangan sampah sekitar 75,3\% masyarakat di Pulau Balang Lompo setiap hari membuang sampah, den- dak melakukan pemilahan sampah yaitu di RW 1.

Hasil Analisis Air Limbah Domestik.

Berdasarkan hasil penelitian yang dilakukan terkait fasilitas sanitasi yaitu jamban yang ada di Pulau Balang Lompo hasil survey pada responden didapatkan bahwa $29,2 \%$ tidak memiliki jamban dari 65 rumah. Jadi, kebiasaan buang air besar masyarakat, masih ada yang melakukan di laut 26,2\%. Sekitar 29,2\% melakukan buang air besar di ruang terbuka (tidak punya kloset). Dimana presentase tertinggi pada RW 1 dan RW 4. Untuk persentase 
rumah responden yang anaknya sering BAB dilantai mencapai $36,8 \%$ dengan kategori kadang-kadang. Sebanyak 44,6\% tidak memiliki SPAL, dimana presentase tertinggi adalah di RW 1. Ada yang mengalirkan limbahnya kehalaman yaitu $38,4 \%$.

Hasil Analisis Perilaku Higiene dan Sanitasi. itu.

\section{PEMBAHASAN}

EHRA (Environmental Health Risk Assessment) atau Penilaian Risiko Sanitasi Lingkungan adalah studi yang bertujuan untuk memahami kondisi fasilitas sanitasi dan perilaku-perilaku yang memiliki risiko pada kesehatan warga. Fasilitas sanitasi

\section{Tabel 5. Skoring Risiko Sanitasi Lingkungan}

\begin{tabular}{ccc}
\hline RW & NILAI Indesk Risiko Sanitasi Lingkungan & Skor \\
\hline 1 & 191 & 4 \\
2 & 124 & 1 \\
3 & 125 & 1 \\
4 & 135 & 1 \\
\hline
\end{tabular}

Sumber :Data Primer, 2017

Secara umum, waktu cuci tangan pakai sabun yang paling banyak dipraktekan oleh responden di Pulau Balang Lompo adalah di waktu setelah makan yakni $46,1 \%$. Waktu kedua adalah setelah buang air besar atau BAB, yakni sebesar $30,8 \%$ dan sebagian besar masyarakat tidak melakukan cuci tangan di lima waktu penting yakni $23,1 \%$. Dimana presentase tertinggi adalah RW 1. Hal ini di karenakan kurangnya pengetahuan mengenai lima waktu penting cuci tangan pakai sabun dan kurangnya kesadaran masyarakat akan hal yang diteliti mencakup, sumber air minum, layanan pembuangan sampah, jamban, dan saluran pembuangan air limbah. Sementara, perilaku yang dipelajari adalah yang terkait dengan higinitas dan sanitasi, antara lain, cuci tangan pakai sabun, buang air besar, dan pemilahan sampah rumah tangga. Masalah kesehatan lingkungan di Indonesia yang merupakan negara yang sedang berkembang berkisar pada sanitasi (jamban), penyediaan air bersih, perumahan, pembuangan sampah, dan pembuangan air limbah (Notoatmodjo, 2002). 


\section{Kepemilikan Tempat Sampah}

Kepemilikan tempat sampah menjadi unsur bahaya yang sangat penting diperhatikan terhadap masalah estetika, permasalahan sampah menjadi penyumbang terbesar terhadap persebaran penyakit diare dan penyakit yang berhubungan dengan sanitasi lingkungan sehingga dianggap penting. Khususnya masyarakat di Pulau Balang Lompo masih banyak yang tidak memiliki tempat sampah sehingga sampahnya langsung ke laut. Hal ini dapat memberikan dampak yang cukup besar bagi kesehatan dan kelangsungan hidup mereka sendiri. Dengan demikian, risiko pencemaran dan penyebaran vektor penyakit akibat sampah akan semakin tinggi. Misalnya, penyebaran penyakit akibat vektor lalat dan tikus dimana tempat sampah merupakan tempat untuk mecari makan bagi vektor tersebut. Proses penyebaran vektor ini biasanya melalui makan yang kita makan, dimana lalat yang telah hinggap di tempat sampah kemudian hinggap dimakan kita, sehingga kuman atau bakteri yang ada disampah tersebut berpindah ke makanan kita melalui lalat karena dari sampah tersebut akan hidup mikroorganisme penyebab penyakit dan juga binatang serangga sebagai penyebar penyakit. Hal ini, akan menimbulkan gangguan penyakit pada masyarakat misalnya penyakit diare. Pengelolaan sampah yang baik, bukan untuk kepentin- gan kesehatan saja, tetapi juga untuk keindahan lingkungan (Soekidjo Notoatmodjo, 2007). Beberapa literatur menyebutkan bahwa cara pembuangan sampah di lubang sampah, dibakar, baik dihalaman atau diluar rumah, merupakan cara yang aman pula. Namun, dalam konteks wilayah-wilayah terpencil dimana tidak ada sarana ataupun sarana prasarana jasa pengangkutan sampah maka alternatif tersebut tidak berlaku di $\mathrm{Pu}-$ lau Balang Lompo. Hal ini dapat menciptakan tantangan khusus bagi Pemerintah dalam menghadapi dan menangani masalah limbah padat rumah tangga. Semakin terpencil suatu wilayah maka semakin sulit pula menangani masalah pembuangan sampah. Sebagai firman Allah swt. pada QS.Ar$\operatorname{rum} / 30: 41$

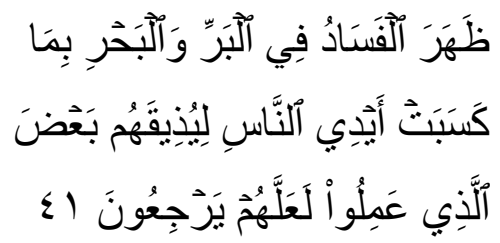

Terjemahnya :

"Telah terjadi (tampak) kerusakan di darat dan di laut karena perbuatan tangan manusia, supaya Allah akan merasakana kepada mereka sebagian dari (akibat tindakan mereka) agar mereka kembali (ke jalan yang benar)" (DepartemenAgam $R I, 2005)$. 
Dalam surah ar-rum ayat 41 di atas juga dapat dipahami bahwa kerusakankerusakan yang terjadi di muka bumi ini, baik dalam bentuk kerugian karena perbuatan manusia, ataupun bencana alam yang menimpa manusia pada hakikatnya adalah akibat dari perbuatannya sendiri, maka timbullah berbagai kesulitan hidup dan malapetaka yang menimpa manusia (Gassing,2005).

\section{Air Limbah Domestik}

Permasalahan yang lain ditemukan adalah masalah air limbah domestik. Jamban adalah suatu bangunan yang digunakan untuk membuang dan mengumpulkan kotoran manusia dalam suatu tempat tertentu, sehingga kotoran tersebut tidak menjadi penyebab penyakit dan mengotori lingkungan pemukiman. (Soeparman, 2002). Beberapa faktor penyebab masyarakat di $\mathrm{Pu}$ lau Balang Lompo tidak membuat jamban yaitu dari segi ekonomi. Mahalnya bahan bangunan membuat masyarakat enggan berfikir untuk membuat jamban dan keterbatasan lahan untuk pembuatan jamban, serta sarana dan prasarana dalam pembuatan jamban. Masyarakat yang tidak memiliki sarana jamban memberikan risiko 17,25 kali terkena diare pada bayi dan balita. (Adisasmito, dkk, 2007). Dan ketidak adaan SPAL dapat menyebabkan adanya genangan di halaman rumah, selain itu menyebabkan mudahnya perkembangan bibit penyakit akan menginfeksi manusia. Hal ini yang terjadi di Pulau Balanmg Lompo bahwa terdapat genangan di beberapa rumah responden yang menimbulkan bau busuk dan mengurai nilai estetika. Oleh karena itu, ini akan meningkatkan risiko kesehatan masyarakat terhadap masalah penyakit yang disebabkan oleh lingkungan.

Pada dasarnya, perilaku BABS dipengaruhi oleh beberapa faktor yang berkaitan dengan penggunaan jamban dan perilaku BABS yakni ada hubungan antara pengetahuan dan sikap ibu terhadap perilaku buang air besar (BAB) yang sehat yaitu mencapai $90 \%$ dan $93,7 \%$ toilet dipastikan berfungsi dengan baik. (Sangchantr, 2009). Perubahan perilaku buang air besar sembarangan tergantung kesadaran seseorang untuk menggunakan fasilitas, akses jamban dan presepsi seseorang tentang tinja dan hubungannya dengan penyakit. Hasil penelitian yang dilakukan terkait penggunaan jamban bahwa terdapat hubungan antara sikap, kepemilikan jamban dan ketersediaan air bersih dengan perilaku keluarga menggunakan jamban. (Lahiri, 2003).

\section{Perilaku Higiene dan Sanitasi}

Permasalahan higienitas akibat pencemaran tinja/ kotoran manusia (feses) 
adalah sumber utama dari virus, bakteri dan pathogen lainnya. Jalur pencemaran yang diketahui sehingga sampai ke mulut manusia termaksud balita adalah 4F, yaitu fluids (air), fields (tanah), flies (lalat), dan fingers (jari/tangan). Siklus ini dimulai dari kontaminansi tinja manusia melalui pencemaran air dan tanah penyebab serangga dan tangan kotor yang dipindahkan kemakanan sehingga dikonsumsi oleh manusia. Proses penularan penyakit tersebut di pengaruhi oleh karakteristik penjamu (imunitas, gizi, status kesehatan, usia, jenis kelamin) dan perilaku penjamu (kebersihan diri dan kebersihan makanan). Jalur ini memperlihatkan bahwa salah satu upaya prevensi cemaran yang sangat efektif dan efisien adalah perilaku manusia yang memblok jalur fingers. Ini bisa dilakukan dengan mempraktekan cuci tangan pakai sabun di waktu-waktu yang tepat. Dalam meta-studi, ditemukan bahwa praktek cuci tangan pakai sabun dapat menurunkan risiko insiden diare sebanyak 42-47\%. Bila dikonversikan, langka sederhana ini dapat menyelamatkan sekitar 1 juta anak-anak di dunia. (Curtis, 2001). Beberapa penelitian menyebutkan tentang hubungan dan pengaruh sanitasi buruk oleh karakteristik dan perilaku masyarakat terhadap terjadinya penyakit infeksi. Diperkirakan $88 \%$ kematian akibat diare di dunia disebabkan oleh kualitas air, sanitasi dan hygiene yang buruK. Dalam studi disebut- kan juga bahwa meningkatnya sistem pembuangan tinja efektif mencegah kejadian diare.

Setelah dilakukan identifikasi masalah kemudian keseluruhan permasalahan yang ditemukan, maka dilakukan penilaian risiko terkait permasalahan sanitasi lingkungan. Penilaian risiko sanitasi lingkungan merupakan salah satu cara memberikan penilaian bahaya sanitasi lingkungan khususnya di Pulau Balang Lompo. Penentuan besarnya risiko, dilakukan dengan cara pemberian bobot pada unsur bahaya. Bobot yang diberikan pada masing-masing komponen variabel bahaya kemudian dikumulatifkan untuk mendapatkan nilai Indeks Risiko Sanitasi Lingkungan .

Berdasarkan hasil perhitungan, didapatkan bahwa RW 1 berada pada kategori Risiko sangat tinggi, RW 2 dengan kategori Risiko rendah, RW 3 dengan kategori Risiko rendah dan untuk RW 4 dengan kategori Risiko rendah . Dari hasil tersebut dapat dilihat bahwa RT 1 pendidikan terakhirnya hanya tamat SD. Tingkat pendidikan responden memiliki pengaruh terhadap perilaku seseorang khususnya perilaku higienitas. WHO menjelaskan bahwa tingkat pendidikan akan menentukan pengetahuan seseorang yang akan membentuk perilaku serta peningkatan jumlah penduduk ataupun kepadatan penduduk di suatu wilayah memberikan dampak yang serius 
terhadap daya dukung lingkungan, karena kenaikan jumlah penduduk akan meningkatkan konsumsi pemakaian air bersih yang berdampak terhadap peningkatan jumlah air limbah domestik.

\section{KESIMPULAN}

Berdasarkan hasil penelitian tentang penilaian risiko kesehatan lingkungn di $\mathrm{Pu}$ lau Balang Lompo Kelurahan Mattiro Sompe Kecamatan Liukang Tupabbiring Kabupaten Pangkajene dan Kepulauan, dapat disimpulkan bahwa: (1) Penilaian risiko kesehatan lingkungan di Pulau Balang Lompo Kelurahan Mattiro Sompe Kecamatan Liukang Tupabbiring Kabupaten Pangkajene dan Kepulauan di dapatkan bahwa RW 1 berada pada kategori Risiko sangat tinggi dengan nilai indeks risiko 191, RW 2 dengan kategori Risiko rendah dengan nilai indeks risiko 124, RW 3 dengan kategori Risiko rendah dengan nilai indeks risiko125 dan untuk RW 4 dengan kategori Risiko rendah dengan nilai indeks risiko 135. (2) Bahaya kesehatan lingkungan yang tertinggi meliputi kepemilikan tempat sampah dan pengolahannya yaitu di RW 1 . (3) Bahaya kesehatan lingkungan yang tertingi meliputi kepemilikan Saluran Pembuangan Air Limbah (SPAL) dan pembuangan akhir air limbah yaitu di RW 1 . (4) Bahaya kesehatan lingkungan yang tertingi meliputi kepemilikan jamban yaitu di RW 1. (5) Peluang keterpaparan bahaya sanitasi lingkungan yang tertinggi dalam bentuk perilaku berisiko (perilaku) meliputi: perilaku Cuci Tangan Pakai Sabun yaitu RW 1 dan BAB Sembarangan yaitu di RW 1.

\section{SARAN}

Pemerintah khususnya Dinas Kesehatan Kabupaten Pangkajene dan Kepulauan melakukan penyuluhan mengenai sampah serta dampaknya bagi lingkungan dan manusia dan melakukan pelatihan mengenai pengelolaan sampah yang bisa didaur ulang. Kemudian penyediaan sarana dan prasarana pengangkutan sampah. (2) Saran mengenai pemasalahan saluran pembuangan air limbah (SPAL) rumah tangga dan banjir di Pulau Balang Lompo Kelurahan Mattiro Sompe Kecamatan Liukang Tupabbiring Kabupaten Pangkajene dan Kepulauan, agar pemerintah Kabupaten Pangkajene dan Kepulauan khususnya Dinas Kesehatan Kabupaten Pangkajene dan Kepulauan bekerja sama dengan puskesmas kecamatan melakukan penyuluhan mengenai pentingnya SPAL dan bahaya membuang limbah di sembarang tempat. (3) Saran mengenai permasalahan pembuangan kotoran manusia (tinja) atau jamban, agar pemerintah Kabupaten Pangkajene dan Kepulauan khususnaya pemerintah desa melakukan penyuluhan mengenai 
bahaya buang air besar sembarangan (BABS), pengadaan beberapa WC umum dan mengadakan bantuan pengadaan jamban rumah tangga di Pulau Balang Lompo dengan menyediakan bahan-bahan pembuatan jamban. (4) Saran mengenai permasalahan higienitas dan sanitasi rumah tangga di Pulau Balang Lompo Kelurahan Mattiro Sompe Kecamatan Liukang Tupabbiring Kabupaten Pangkajene dan Kepulauan agar masyarakat bisa diberikan beberapa pengetahuan atau melakukan penyuluhan mengenai perilaku hidup bersih dan sehat (PHBS), khususnya bagi anak-anak dan ibu rumah tangga. (5) Saran Untuk Peneliti selanjutnya, bahwa hasil penelitian ini di harapkan jadi penunjang penelitian selanjutnya yang relevan dengan penelitian ini.

\section{DAFTAR PUSTAKA}

Adisasmito, W. (2007). Faktor Risiko Diare Pada Bayi dan Balita di Indonesia. Systematic Review Penelitian Akademik Bidang Kesehatan Masyarakat, Vol. 11. No.1. Hal.110.

Curtis. (2001). Evidence of behaviour change following a hygiene promotion programme in Burkina Faso. Bulletin Of The World Health Organization, Vol. 79 (6): 0042-9686.

Departemen Agama Republik Indonesia. (2005). Al Quran Dan Terjemahnya.
Surabaya : CV Penerbit Al Jumanatul Ali Art.

Departemen Kesehatan RI. (2016). Profil Kesehatan Kabupaten Pangkep.

Gassing, Qadir. (2005). Fiqih Lingkungan : Telaah Krisis Tentang Penerapan Hukum Takfili Dalam Pengelolaan Lingkungan Hidup. Makassar: Alauddin Press.

ISSDP. (2007). Penilaian Resiko Kesehatan Lingkungan Kota Blitar. Jakarta: Indonesia Sanitation Sector Development Program.

Lahiri, S \& Chanthaphone, S. (2003). Water, sanitation and hygiene: a situation analysis paper for Lao PDR. International Journal of Environmental Health Research, Vol. 13. p.14 - 107.

Marwah, dkk. (2014). Penilaian Risiko Kesehatan Lingkungan Pulau Bonetambung. Skripsi. Kota Makassar. Fakultas Kesehatan Masyarakat Universitas Hasanudin.

Notoatmodjo. (2002). Ilmu Kesehatan Masyarakat. Jakarta: Rineke Cipta.

Notoatmodjo, S. (2007). Kesehatan Masyarakat:Ilmuwan Seni, Eds, revisi. Jakarta: PT.Rineka cipta.

RISKESDAS (2013). "Data Statistik Kesehatan Lingkungan Tahun 2013”. Jakarta: Departemen Kesehatan RI.

Sangchantr, S, dkk. (2009). Pengetahuan, Sikap dan Perilaku Terhadap Air, Sanitasi dan Higiene di Aceh Health Meseenger. Pembawa Pesan Kesehatan.

Soeparman dan Suparmin. (2002). Pembuangan Tinja dan Limbah Cair. Jakarta: Penerbit Buku Kedokteran. 